\title{
PERILAKU HIDUP BERSIH DAN SEHAT (PHBS) SERTA PERILAKU GIZI SEIMBANG IBU KAITANNYA DENGAN STATUS GIZI DAN KESEHATAN BALITA DI KABUPATEN BOJ ONEGORO, J AWA TIMUR
}

\author{
(Clean and Healthy Lifestyle Behavior, and Balance Diet Behavior of Mothers \\ and it's Relation to Nutritional and Health Status of Children Under Five Years \\ in Bojonegoro, East J ava)
}

Linda Dwi J ayanti ${ }^{1}$, Yekti Hartati Effendi ${ }^{2 *}$, dan Dadang Sukandar ${ }^{2}$

\footnotetext{
${ }^{1}$ Program Studi Gizi Masyarakat, Fakultas Ekologi Manusia (FEMA), IPB

2 Departemen Gizi Masyarakat, Fakultas Ekologi Manusia (FEMA), IPB

* Alamat korespondensi: Departemen Gizi Masyarakat, Fakultas Ekologi Manusia, Institut Pertanian Bogor, Bogor 16680. Telp: 0251-8621258; Fax: 0251-8622276; Email: yh.effendi@gmail.com
}

\begin{abstract}
ABST RACT
The purpose of this study was to determine nutritional knowledge, clean and healthy lifestyle behavior, and balanced diet on maternal behavior, as well as its relationship with nutritional and health status and children under 5 years health. The cros sectional study was conducted during March-April 2011. The population in this study consist of all the children under five living in Campurejo village, Bojonegoro districts East Java Province. The respondents were mothers of toddlers who were selected as samples. Total samples in this study were 55 toddlers. The results showed that maternal nutrition knowledge is positively correlated with clean and healthy lifestyle behavior $(p<0.05$ and $r=0.706)$, and also correlated with balanced diet on behavior ( $p \ll 0.05$ and $r=0537$ ). Clean and healthy lifestyle behavior is positively correlated with nutritional status of samples $(p \ll 0.05$ and $r=0.325)$, but not correlated with the incidence of illness in the samples. Balanced diet on maternal behavior is not correlated with the nutritional status of samples and the incidence of illness in the samples.
\end{abstract}

Key words: clean and healthy lifestyle, balance diet, health status, children under five.

\section{PENDAHULUAN}

Salah satu tujuan pembangunan nasional di Indonesia adalah meningkatkan kualitas sumber daya manusia Indonesia sebagai modal dasar pembangunan di masa mendatang. Tujuan pembangunan nasional tersebut kemudian direalisasikan dalam Tujuan Pembangunan Milenium atau Millennium Development Goals (MDGs). Adapun target utama MDGs dalam hal menurunkan angka kematian anak adalah menurunkan angka kematian balita sebesar dua pertiganya antara tahun 1990 hingga tahun 2015 (Stalker 2008).

Menurut Hardinsyah dan Martianto (1988), status gizi merupakan salah satu petunjuk untuk menilai kualitas sumber daya manusia, dan perilaku konsumsi pangan seseorang akan menentukan status gizi orang tersebut. Pada tingkat rumah tangga, status gizi dipengaruhi oleh kemampuan rumah tangga dalam menyediakan makanan yang cukup baik dari segi kualitas dan kuantitasnya, pola asuh anak, pengetahuan gizi, serta faktor sosio budaya lainnya. Periode kritis anak berada pada lima tahun pertama setelah kelahiran. Jika pertumbuhan dan perkembangan anak pada periode ini optimal, maka akan dapat tumbuh menjadi individu yang berkualitas (Khomsan et al. 2009).

Perilaku hidup bersih dan sehat (PHBS) pada hakikatnya merupakan perilaku pencegahan oleh individu atau keluarga dari berbagai penyakit. Salah satu sasaran penerapan program PHBS adalah pada tatanan rumah tangga, yang bertujuan untuk meningkatkan derajat kesehatan keluarga dan produktivitas kerja setiap anggota keluarga (Depkes RI 2006). Cakupan PHBS di Kabupaten Bojonegoro masih tergolong rendah, sebab berdasarkan survei pada tahun 2008 terhadap 23947 rumah yang dipantau, jumlah keluarga yang melakukan PHBS baru mencapai 9425 rumah (39.36\%) (Dinkes Kabupaten Bojonegoro 2008).

Masalah kurang gizi pada balita dapat juga disebabkan oleh perilaku ibu dalam pemilihan bahan makanan. Menurut Khomsan (2009), ibu yang memiliki pengetahuan gizi yang baik akan mempraktekkan perilaku gizi yang baik dalam hal memilih makanan yang 
bergizi, beragam, dan berimbang untuk balitanya, dan sebaliknya ibu yang pengetahuan gizinya kurang akan cenderung memiliki perilaku gizi yang kurang baik, termasuk dalam hal memilih makanan untuk anak sehingga memberikan dampak yang kurang baik pada status gizi balita. Persentase balita dengan status gizi kurang di Kabupaten Bojonegoro masih tergolong cukup tinggi, yaitu 14.22 persen (Bappeda 2008).

Berdasarkan beberapa hal tersebut di atas, penelitian ini akan mengkaji tentang perilaku hidup bersih dan sehat (PHBS) dan perilaku gizi seimbang ibu serta kaitannya dengan status gizi dan kesehatan balita di Kabupaten Bojonegoro.

\section{METODE}

\section{Desain dan Lokasi}

Desain penelitian ini adalah population survey dengan teknik wawancara. Penelitian dilaksanakan di Desa Campurejo, Kecamatan Bojonegoro, Kabupaten Bojonegoro. Pemilihan lokasi penelitian tersebut berdasarkan pertimbangan ada 1.8 persen balita dengan status gizi buruk dan 10.9 persen balita dengan status gizi kurang, serta cakupan penerapan PHBS ibu masih tergolong rendah. Penelitian dilaksanakan pada bulan Maret hingga April 2011.

\section{Cara Pemilihan Contoh}

Contoh dalam penelitian ini adalah balita yang tercatat di posyandu Desa Campurejo, Kecamatan Bojonegoro, Kabupaten Bojonegoro. Adapun populasi pada penelitian ini adalah seluruh balita yang tinggal di Desa Campurejo, Kecamatan Bojonegoro, yaitu sebanyak 242 balita. Responden adalah ibu balita yang terpilih sebagai contoh. Perkiraan jumlah minimal contoh ditentukan menggunakan rumus Lemeshow et al. (1997), yaitu 49 contoh yang dipilih dari tiga posyandu di desa terpilih. Kriteria pemilihan contoh adalah balita berusia 13-60 bulan yang tinggal bersama ibunya, tercatat di posyandu di desa terpilih, dan responden bersedia untuk diwawancarai. Calon contoh diambil dari populasi yang memenuhi kriteria, yaitu sebanyak 190 balita, kemudian dipilih sebagai contoh menggunakan metode acak stratifikasi dengan alokasi proporsional sehingga diperoleh 55 contoh yang memenuhi kriteria.

\section{J enis dan Cara Pengumpulan Data}

Data primer meliputi karakteristik contoh (umur dan jenis kelamin), karakteristik keluarga (umur, pendidikan, besar keluarga, pekerjaan, dan pendapatan orang tua), pengetahuan gizi, PHBS dalam keluarga, perilaku gizi seimbang ibu, konsumsi pangan balita, status gizi, dan kesehatan balita. Data sekunder meliputi gambaran umum lokasi penelitian dan daftar nama pasangan ibu dan balita yang memenuhi kriteria penelitian. Pengambilan data primer dilakukan dengan wawancara langsung menggunakan kuesioner dan recall 2x24 jam, sedangkan data sekunder diperoleh dari pencatatan arsip desa dan data yang tersedia di puskesmas dan posyandu.

\section{Pengolahan dan Analisis Data}

Pengolahan data yang dilakukan meliputi editing, coding, entry, cleaning dan analisis. Hubungan antar variabel dianalisis menggunakan uji korelasi Pearson dan Rank Spearman.

Data karakteristik balita dan karakteristik keluarga ditabulasi dan dianalisis secara deskriptif. Data mengenai pengetahuan gizi ibu diukur menggunakan 20 pertanyaan tentang definisi dan jenis zat gizi dalam pangan, manfaat zat gizi dan akibat kekurangan zat gizi tertentu, serta periode pemberian ASI eksklusif. Berdasarkan 20 pertanyaan tersebut, jawaban benar diberikan skor 1 dan jawaban salah diberikan skor 0 , sehingga diperoleh total nilai terendah 0 dan skor tertinggi 20. Pengetahuan gizi ibu kemudian diklasifikasikan menjadi tiga kategori berdasarkan total nilai, yaitu kategori rendah apabila total nilai $\varangle 60$ persen, kategori sedang apabila total nilai antara 60-80 persen, dan tinggi apabila total nilai >80 persen (Khomsan 2000).

Perilaku hidup bersih dan sehat (PHBS) diukur menggunakan 16 pertanyaan indikator PHBS tatanan rumah tangga yang mencakup 9 pertanyaan indikator perilaku dan 7 pertanyaan indikator lingkungan. Pertanyaan diberikan dalam bentuk tertutup dengan pilihan jawaban "ya" atau "tidak". Berdasarkan 16 pertanyaan yang diajukan, apabila responden menjawab "ya" antara 1-4 pertanyaan, maka termasuk klasifikasi keluarga sehat 1; apabila menjawab "ya" antara 5-8 pertanyaan, maka termasuk klasifikasi keluarga sehat 2; apabila menjawab "ya" antara 9-12 pertanyaan, maka termasuk klasifikasi keluarga sehat 3; dan apabila menjawab "ya" antara 13-16 pertanyaan, 
maka termasuk klasifikasi keluarga sehat 4 (Depkes 2008 dalam Effendi dkk 2010).

Perilaku gizi seimbang ibu diukur dengan 10 pertanyaan tentang penganekaragaman makanan, pola hidup bersih, aktivitas fisik, dan pemantauan berat badan balita. Pengukuran perilaku gizi seimbang dilakukan menggunakan pertanyaan tertutup dalam bentuk multiple choice, dengan pilihan jawaban: a) selalu, b) kadang-kadang, dan c) tidak pernah. Berdasarkan 10 pertanyaan yang diajukan, diberikan skor 1 untuk pilihan jawaban yang termasuk kategori rendah, nilai 2 untuk pilihan jawaban yang termasuk kategori sedang, dan nilai 3 untuk pilihan jawaban yang termasuk kategori baik, sehingga diperoleh total nilai terendah 10 dan total nilai tertinggi 30. Adapun kategori total nilai, yaitu kategori rendah 10-16, kategori sedang 17-23, dan kategori baik (Slamet 1993).

Data jumlah konsumsi balita dihitung menggunakan metode recall selama $2 \times 24$ jam. Data konsumsi pangan yang diperoleh dikonversikan ke dalam bentuk energi, protein, vitamin $A$, vitamin $C$, dan $F e$ menggunakan DKBM dan kemudian dibandingkan dengan kecukupan konsumsi zat gizi berdasarkan tabel AKG 2004.

Menurut Depkes (1996), tingkat kecukup an energi dan protein dibedakan menjadi lima cut-off points yaitu defisit tingkat berat $(<70 \%$ $A K G)$, defisit tingkat sedang (70-79\% AKG), defisit tingkat ringan (80-89\% AKG), normal (90-119\% AKG), serta berlebih $\geq(120 \%$ AKG).

Adapun klasifikasi tingkat kecukupan zat besi $(\mathrm{Fe})$, vitamin $\mathrm{A}$, dan vitamin $\mathrm{C}$ dibagi menjadi dua kategori menurut Gibson (2005), yaitu defisit apabila $<77$ persen AKG serta cukup apabila $\geq 77$ persen AKG.

Status gizi contoh dihitung berdasarkan indeks $\mathrm{BB} / \mathrm{U}, \mathrm{TB} / \mathrm{U}$, dan $\mathrm{BB} / \mathrm{TB}$, menggunakan software WHO Anthroplus 2007. Status kesehatan balita diamati berdasarkan kejadian sakit pada satu bulan terakhir yang meliputi jenis penyakit yang diderita, pernah/tidaknya sakit, frekuensi sakit, serta lama menderita sakit.

\section{HASIL DAN PEMBAHASAN}

\section{Karakteristik Sosial Ekonomi Keluarga}

Sebaran umur orang tua contoh dikelompokkan menjadi empat golongan, yaitu kelompok remaja ( $<20$ tahun), kelompok dewasa muda (20-30 tahun), kelompok dewasa madya
(31-50 tahun), dan dewasa lanjut ( $>50$ tahun) (WKNPG 2004). Lebih dari separuh ayah (54.5\%) tergolong kelompok umur dewasa madya dengan rata-rata umur 33 tahun, sedangkan sebanyak 67.3 persen ibu tergolong kelompok umur dewasa muda dengan ratarata umur 30 tahun.

Rata-rata pendidikan terakhir orang tua contoh, baik ayah maupun ibu adalah tamat $\mathrm{SMU} /$ sederajat. Keseluruhan orang tua contoh memiliki pendidikan minimal 9 tahun atau setingkat tamat SMP. Selain itu, terdapat seki$\operatorname{tar} 12.7$ persen ayah dan 10.9 persen ibu contoh yang memiliki pendidikan terakhir hingga sarjana.

J enis pekerjaan ayah contoh yang paling banyak adalah sebagai pegawai swasta (41.8\%), sedangkan jenis pekerjaan ibu contoh yang paling banyak adalah sebagai ibu rumah tangga (76.4\%). Selain itu, diketahui pula terdapat 12.7 persen ayah dan 7.3 persen ibu contoh yang berprofesi sebagai pegawai negeri (PNS).

Rata-rata penghasilan perkapita per bulan keluarga contoh (72.73\%) berada di atas batas garis kemiskinan Provinsi Jawa Timur, yaitu Rp 219727 (BPS 2010). Sebanyak 56.36 persen keluarga contoh tergolong keluarga sedang (5-7 orang). Sementara itu, 41.82 persen keluarga contoh tergolong keluarga kecil ( $\leq 4$ orang), dan 1.82 persen lainnya merupakan keluarga besar, yaitu $\geq 9$ orang.

\section{Karakteristik Balita}

Jumlah contoh dengan jenis kelamin laki-laki lebih banyak (54.54\%) dibandingkan jumlah contoh dengan jenis kelamin perempuan (45.45\%). Hampir separuh contoh berumur antara 25-36 bulan dengan standar deviasi 7.7 dan hanya 9 persen contoh yang berusia antara 13-24 bulan.

Lebih dari separuh balita tidak diberikan ASI eksklusif oleh ibunya hingga berumur 6 bulan. Sebagian besar balita hanya diberikan ASI eksklusif hingga umur 3-4 bulan. Balita yang tidak mendapatkan ASI eksklusif hingga umur 6 bulan adalah sebanyak 72.7 persen, sedangkan balita yang mendapatkan ASI eksklusif hingga umur 6 bulan hanya sebanyak 27.3 persen.

\section{Pengetahuan Gizi lbu}

Rata-rata pengetahuan gizi ibu tergolong sedang $(61.82 \%)$, sedangkan responden yang pengetahuan gizinya baik sebanyak 38.18 
persen. Secara keseluruhan, tidak terdapat responden yang memiliki pengetahuan gizi rendah. Seluruh responden yang tingkat pendidikan terakhirnya SMP/sederajat memiliki tingkat pengetahuan gizi sedang. Sebanyak 43.64 persen responden yang tingkat pendidikan terakhirnya adalah SMU/ sederajat memiliki tingkat pengetahuan gizi sedang, dan sebanyak 20 persen lainnya memiliki tingkat pengetahuan gizi baik. Responden yang memiliki tingkat pendidikan terakhir diploma atau sarjana, seluruhnya memiliki tingkat pengetahuan gizi baik. Hal ini menunjukkan bahwa responden yang memiliki tingkat pendidikan lebih tinggi, memiliki tingkat pengetahuan lebih baik dibandingkan dengan responden yang tingkat pendidikannya lebih rendah.

\section{Perilaku Hidup Bersih dan Sehat (PHBS) dalam Keluarga}

Sebanyak 60 persen responden termasuk ke dalam kategori keluarga sehat 3, dengan penerapan PHBS kategori sedang. Sementara itu, 40 persen responden lainnya termasuk ke dalam kategori keluarga sehat 4, dengan penerapan PHBS kategori baik. Tidak terdapat responden yang termasuk ke dalam kategori keluarga sehat 1 dan keluarga sehat 2, sehingga dapat diketahui bahwa tidak ada responden yang penerapan PHBS dalam keluarganya tergolong buruk atau kurang.

Berdasarkan 16 pertanyaan yang diajukan tentang indikator PHBS, dapat diketahui bahwa seluruh responden melakukan imunisasi lengkap pada bayi dan balitanya, baik di posyandu, bidan, atau dokter. Selain itu, seluruh responden menggunakan air yang masak untuk keperluan minum keluarga. Semua responden juga menjawab melakukan perilaku seksual secara sehat, serta tidak pernah menggunakan narkotika dan obat-obatan terlarang. Hanya 9. 09 persen responden yang memeriksakan kesehatan secara berkala dengan pap smear, dan hanya 10.9 persen yang melakukan SADARI (periksa payudara sendiri) secara berkala. Hal ini menunjukkan bahwa kesadaran responden akan kesehatan organ tubuh dan alat reproduksi masih sangat kurang.

\section{Perilaku Gizi Seimbang lbu}

Hampir semua responden (87.3\%) memiliki gizi seimbang baik dan hanya 12.7 persen yang memiliki perilaku gizi seimbang kategori sedang. Tidak ada responden yang memiliki perilaku gizi seimbang rendah. Rata-rata perilaku gizi seimbang responden termasuk ke dalam kategori baik, yakni dengan total nilai rata-rata 25 dan standar deviasi 1.56.

Menurut Kurniasih dkk (2010), perilaku gizi seimbang ibu dibedakan menjadi empat, yakni dalam hal penganekaragaman makanan, pola hidup bersih keluarga, aktivitas fisik, serta pemantauan berat badan balita. Dalam hal penganekaragaman makanan, tidak terdapat responden yang perilaku gizi seimbangnya termasuk kategori rendah. Hal ini menunjukkan bahwa semua responden telah memperhatikan pola penganekaragaman jenis makanan untuk balita dan keluarga. Dalam hal pola hidup bersih keluarga, sebanyak 87.27 persen menjawab selalu membiasakan balita untuk mencuci tangan dengan air bersih dan sabun setelah makan dan bermain, serta sebanyak 98.18 persen menjawab selalu melatih anak untuk buang air kecil dan buang air besar di kamar mandi.

Aktivitas fisik responden dan keluarga masih tergolong sangat rendah. Hal ini ditunjukkan dengan hampir seluruh responden (92.73\%) menjawab melakukan olahraga/aktivitas fisik $\leq 1$ kali setiap minggunya. Ratarata responden tidak pernah melakukan olahraga secara rutin setiap minggunya dengan alasan tidak memiliki waktu untuk melakukan aktivitas fisik akibat terlalu sibuk dengan keperluan rumah tangga. Selain itu, terdapat pula responden yang beralasan tidak pernah atau jarang melakukan aktivitas fisik bersama keluarga karena malas. Hampir seluruh responden (94.55\%) menjawab selalu memantau berat badan balitanya ke posyandu atau klinik setiap bulannya. Selain itu, lebih dari separuh responden (50.91\%) selalu memantau kebiasaan jajan anak balitanya. Hal tersebut menunjukkan perilaku gizi seimbang ibu dalam hal pengontrolan berat badan balita termasuk ke dalam kategori baik.

\section{Konsumsi dan Tingkat Kecukupan Energi dan Zat Gizi}

Tingkat kecukupan energi dan zat gizi contoh dihitung dengan cara membandingkan konsumsi energi dan zat gizi dengan angka kecukupannya. Rata-rata tingkat kecukupan energi contoh masih lebih rendah yaitu hanya 84. 6 persen, serta tergolong defisit tingkat ringan ( $<0 \%$ angka kecukupan energi). Sementara itu, tingkat kecukupan protein contoh tergolong berlebih (151\%). Kecukupan protein yang berlebih salah satunya disebabkan karena rata-rata contoh lebih banyak mengonsumsi makanan sumber protein baik protein hewani maupun nabati dibandingkan dengan makanan 
sumber energi. Rata-rata tingkat kecukupan vitamin $A$, vitamin $C$, dan zat besi contoh tergolong cukup karena $>77$ persen angka kecukupan, yaitu masing-masing 96.1 persen, 102.9 persen, dan 130.5 persen.

\section{Status Gizi Balita}

Berdasarkan pengukuran dengan indeks $\mathrm{BB} / \mathrm{U}$, diketahui bahwa rata-rata balita berstatus gizi normal (83.64\%). Meski demikian, masih terdapat sebanyak 1.82 persen balita dengan status gizi buruk, 10.91 persen dengan status gizi kurang, serta 3.64 persen dengan status gizi lebih (Tabel 1 ).

Tabel 1 Status Gizi Balita berdasarkan Pengukuran Z-Skor dengan Indeks BB/ U, TB/ U, dan BB/TB

\begin{tabular}{|c|c|c|}
\hline Status Gizi dgn indeks BB/U & $\mathbf{n}$ & $\%$ \\
\hline Gizi Buruk ( $Z \leq-3 \mathrm{SD})$ & 1 & 1.82 \\
\hline Gizi Kurang (-3 SD $<Z<-2$ SD) & 6 & 10.91 \\
\hline Gizi Baik $(-2 \mathrm{SD}<\mathrm{Z}<2 \mathrm{SD})$ & 46 & 83.64 \\
\hline Gizi Lebih ( $Z \geq 2$ SD) & 2 & 3.64 \\
\hline Total & 55 & 100.00 \\
\hline Rata-rata \pm SD & \multicolumn{2}{|c|}{$-0.93 \pm 1.26$} \\
\hline Status Gizi dgn indeks TB/U & $\mathbf{n}$ & $\%$ \\
\hline Sangat pendek $(Z \leq-3 S D)$ & 15 & 27.27 \\
\hline Pendek (-3 SD < Z <-2 SD) & 10 & 18.18 \\
\hline Normal $(-2 \mathrm{SD}<\mathrm{Z}<2 \mathrm{SD})$ & 30 & 54.55 \\
\hline Tinggi ( $Z \geq 2$ SD) & 0 & 0.00 \\
\hline Total & 55 & 100.00 \\
\hline Rata-rata \pm SD & \multicolumn{2}{|c|}{$-2.05 \pm 1.50$} \\
\hline Status Gizi dgn indeks BB/TB & $\mathbf{n}$ & $\%$ \\
\hline Kurus $(-3 \mathrm{SD}<\mathrm{Z}<-2$ SD) & 1 & 1.82 \\
\hline Normal (-2 SD < Z <2 SD) & 45 & 81.82 \\
\hline Gemuk ( $Z \geq 2$ SD) & 9 & 16.36 \\
\hline Total & 55 & 100.00 \\
\hline Rata-rata \pm SD & \multicolumn{2}{|c|}{$0.44 \pm 1.88$} \\
\hline
\end{tabular}

Berdasarkan indeks TB/U, sebanyak 54.55 persen contoh memiliki status gizi normal, sedangkan 45.45 persen lainnya berstatus gizi stunting (pendek). Menurut Riyadi (2003), stunting mencerminkan proses kegagalan dalam mencapai pertumbuhan linear sebagai akibat dari keadaan gizi atau kesehatan yang abnormal. Berdasarkan pengukuran dengan in deks BB/TB, dapat diketahui bahwa sebagian besar balita (81.82\%) berstatus gizi normal. Sebanyak 16.36 persen balita berstatus gizi gemuk, dan sebanyak 1.82 persen contoh lainnya berstatus gizi kurus (wasting).

\section{Status Kesehatan Balita}

Hampir semua balita (96.36\%) pernah mengalami sakit, dan hanya 3.64 persen yang tidak mengalami sakit dalam satu bulan terakhir. Jenis penyakit yang paling sering dialami adalah demam (47.27\%), baik demam yang disertai dengan penyakit lain atau tidak
(Tabel 2). Selain itu, batuk disertai dengan flu juga sering dialami oleh contoh (45.45\%). Rata-rata frekuensi contoh mengalami sakit adalah antara 1-2 kali dalam 1 bulan. Tidak terdapat jenis penyakit yang diderita contoh $>2$ kali dalam waktu satu bulan, kecuali diare (1.82\%). Rata-rata lama contoh mengalami sakit adalah antara 1-3 hari.

Tabel 2 Jenis Penyakit yang Pernah Diderita Balita dan Frekuensi Sakit dalam Satu Bulan Terakhir

\begin{tabular}{lcccccc}
\hline \multirow{2}{*}{ Jenis penyakit } & \multicolumn{6}{c}{ Frekuensi } \\
\cline { 2 - 8 } & \multicolumn{2}{c}{$\begin{array}{c}\text { tidak } \\
\text { pernah }\end{array}$} & $\mathbf{1 - 2}$ kali & \multicolumn{2}{c}{ > 2 kali } \\
\cline { 2 - 8 } & $\mathbf{n}$ & $\%$ & $\mathbf{n}$ & $\%$ & $\mathbf{n}$ & $\%$ \\
\hline Panas/ demam & 29 & 52.73 & 26 & 47.27 & - & - \\
Pilek & 35 & 63.64 & 20 & 36.36 & - & - \\
Batuk biasa & 49 & 89.09 & 6 & 10.91 & - & - \\
Batuk \& flu & 30 & 54.55 & 25 & 45.45 & - & - \\
Diare & 36 & 65.45 & 18 & 32.73 & 1 & 1.82 \\
Sakit kulit & 48 & 87.27 & 7 & 12.73 & - & - \\
Lainnya & 53 & 96.36 & 2 & 3.64 & - & - \\
\hline
\end{tabular}

\section{Hubungan Pengetahuan Gizi dengan PHBS Keluarga dan Perilaku Gizi Seimbang lbu}

Berdasarkan uji korelasi Spearman, diketahui bahwa terdapat hubungan signifikan dan positif antara pengetahuan gizi ibu dengan PHBS dalam keluarga $(p<0.05$ dan $r=0.706$ ) (Tabel 3).

Tabel 3 Hubungan Pengetahuan Gizi Ibu dengan PHBS dan Perilaku Gizi Seimbang Ibu

\begin{tabular}{|c|c|c|c|c|c|c|}
\hline \multirow{3}{*}{$\begin{array}{c}\text { PHBS } \\
\text { keluarga }\end{array}$} & \multicolumn{4}{|c|}{ Tingkat Pengetahuan Gizi } & \multirow{2}{*}{\multicolumn{2}{|c|}{ Total }} \\
\hline & \multicolumn{2}{|c|}{ Sedang } & \multicolumn{2}{|c|}{ Baik } & & \\
\hline & $\mathbf{n}$ & $\%$ & $\mathbf{n}$ & $\%$ & $\mathbf{n}$ & $\%$ \\
\hline Sedang & 29 & 52.73 & 4 & 7.27 & 33 & 60.00 \\
\hline Baik & 5 & 9.09 & 17 & 30.91 & 22 & 40.00 \\
\hline Total & 34 & 61.82 & 21 & 38.00 & 55 & 100.00 \\
\hline \multirow{3}{*}{$\begin{array}{l}\text { Perilaku Gizi } \\
\text { Seimbang Ibu }\end{array}$} & \multicolumn{4}{|c|}{ Tingkat Pengetahuan Gizi } & \multirow{2}{*}{\multicolumn{2}{|c|}{ Total }} \\
\hline & \multicolumn{2}{|c|}{ Sedang } & \multicolumn{2}{|c|}{ Baik } & & \\
\hline & $\mathbf{n}$ & $\%$ & $\mathbf{n}$ & $\%$ & $\mathbf{n}$ & $\%$ \\
\hline Sedang & 5 & 9.09 & 2 & 3.64 & 7 & 12.73 \\
\hline Baik & 29 & 52.73 & 19 & 34.55 & 48 & 87.27 \\
\hline Total & 34 & 61.82 & 21 & 38.18 & 55 & 100.00 \\
\hline
\end{tabular}

Terdapat hubungan signifikan antara tingkat pengetahuan gizi ibu dengan perilaku gizi seimbang ibu ( $p<0.05$ dan $r=0.537)$. Hal ini berarti bahwa responden yang memiliki tingkat pendidikan dan pengetahuan gizi lebih tinggi, maka penerapan PHBS dalam keluarga serta perilaku gizi seimbangnya semakin baik pula.

\section{Hubungan Perilaku Gizi Seimbang dengan Tingkat Kecukupan Energi dan Zat Gizi}

Salah satu penerapan perilaku gizi seimbang ibu yang ikut mempengaruhi konsumsi 
serta tingkat kecukupan energi dan zat gizi balita antara lain dalam hal penganekaragaman makanan yang meliputi penyediaan makanan yang beragam serta frekuensi makan yang teratur setiap hari. Namun, berdasarkan hasil uji korelasi Pearson, dapat diketahui bahwa tidak terdapat hubungan yang signifikan antara perilaku gizi seimbang dengan tingkat kecukupan energi dan zat gizi contoh. Terdapat faktor-faktor lain yang diduga juga mempengaruhi tingkat kecukupan energi dan zat gizi contoh, seperti kondisi sakit, kondisi sosial ekonomi keluarga, kesukaan contoh memakan jajanan yang hanya tinggi kalori atau protein saja, serta ketidaksukaan terhadap sayur atau buah-buahan tertentu.

\section{Hubungan Tingkat Kecukupan Energi dan Zat Gizi dengan Status Gizi}

Menurut Soekirman (2000), faktor gizi yang secara langsung mempengaruhi status gizi seseorang adalah konsumsi makanan dan keadaan kesehatan. Akan tetapi, berdasarkan uj i statistik menggunakan korelasi Pearson, diketahui bahwa tidak terdapat hubungan yang signifikan antara tingkat kecukupan energi dan zat gizi dengan status gizi balita.

Status gizi contoh selain dipengaruhi dari tingkat kecukupan energi dan zat gizi juga dipengaruhi oleh faktor-faktor lain seperti kondisi kesehatan dan kualitas serta kuantitas makanan yang dikonsumsi. Kondisi sakit atau infeksi akan mempengaruhi nafsu dan selera makan sehingga kemudian berdampak pada kurangnya asupan energi dan zat gizi dari makanan.

\section{Hubungan PHBS keluarga dengan Status Gizi dan Kejadian Sakit Balita}

Analisis uji korelasi yang dilakukan menunjukkan bahwa terdapat hubungan signifikan dan positif antara PHBS dalam lingkungan keluarga dengan status gizi contoh $(p<0.05$ dan $r=0.325$ ) (Tabel 4). Hal ini berarti bahwa semakin baik PHBS di dalam keluarga maka status gizi contoh akan semakin baik pula. Hasil uji korelasi Spearman menunjukkan bahwa tidak terdapat hubungan yang signifikan antara PHBS dalam lingkungan keluarga dengan kejadian sakit balita ( $p>0.05 r$ : -0.170$)$. Hal ini berarti bahwa keluarga yang selalu menerapkan PHBS dengan baik, belum tentu balitanya tidak pernah sakit, sebab kejadian sakit balita juga dipengaruhi oleh faktor lain selain PHBS dalam keluarga.
Tabel 4. Hubungan PHBS dalam keluarga dengan Status Gizi dan Kejadian Sakit Balita

\begin{tabular}{|c|c|c|c|c|c|c|}
\hline \multirow{3}{*}{$\begin{array}{c}\text { Status Gizi } \\
\text { (BB/TB) }\end{array}$} & \multicolumn{4}{|c|}{ PHBS Keluarga } & \multirow{2}{*}{\multicolumn{2}{|c|}{ Total }} \\
\hline & \multicolumn{2}{|c|}{ Sedang } & \multicolumn{2}{|c|}{ Baik } & & \\
\hline & $n$ & $\%$ & $\mathbf{n}$ & $\%$ & $\mathbf{n}$ & $\%$ \\
\hline Kurus & 1 & 1.82 & 0 & 0.00 & 1 & 1.82 \\
\hline Normal & 30 & 54.55 & 15 & 27.27 & 45 & 81.82 \\
\hline Gemuk & 2 & 3.64 & 7 & 12.73 & 9 & 16.36 \\
\hline \multirow[t]{2}{*}{ Total } & 33 & 60.00 & 22 & 40.00 & 55 & 100 \\
\hline & \multicolumn{4}{|c|}{ PHBS Keluarga } & \multirow{2}{*}{\multicolumn{2}{|c|}{ Total }} \\
\hline \multirow[t]{2}{*}{ Kejadian sakit } & \multicolumn{2}{|c|}{ Sedang } & \multicolumn{2}{|c|}{ Baik } & & \\
\hline & $n$ & $\%$ & $\mathbf{n}$ & $\%$ & & $\%$ \\
\hline Pernah sakit & 31 & 56.36 & 22 & 40.00 & 53 & 96.36 \\
\hline Tidak pernah sakit & 2 & 3.64 & 0 & 0.00 & 2 & 3.64 \\
\hline Total & 33 & 60.00 & 22 & 40.00 & 55 & 100 \\
\hline
\end{tabular}

\section{Hubungan Perilaku Gizi Seimbang dengan Status Gizi dan Kejadian Sakit Balita}

Berdasarkan uji korelasi Spearman, diketahui bahwa tidak terdapat hubungan signifikan antara perilaku gizi seimbang ibu dengan status gizi contoh (Tabel 5), yang berarti bahwa status gizi balita yang baik tidak selalu karena ibu berperilaku gizi seimbang dengan baik, melainkan juga dapat disebabkan oleh banyak faktor lain.

Tabel 5. Hubungan Perilaku Gizi Seimbang dengan Status Gizi dan Kejadian Sakit Balita

\begin{tabular}{|c|c|c|c|c|c|c|}
\hline \multirow{3}{*}{ Status Gizi (BB/TB) } & \multicolumn{4}{|c|}{ Prilaku Gizi Seimbang } & \multirow{2}{*}{\multicolumn{2}{|c|}{ Total }} \\
\hline & \multicolumn{2}{|c|}{ Sedang } & \multicolumn{2}{|c|}{ Baik } & & \\
\hline & $\mathbf{n}$ & $\%$ & $\mathbf{n}$ & $\%$ & $\mathbf{n}$ & $\%$ \\
\hline Kurus & 1 & 1.82 & 0 & 0 & 1 & $\overline{1.82}$ \\
\hline Normal & 6 & 10.91 & 39 & 70.91 & 45 & 81.82 \\
\hline Gemuk & 0 & 0 & 9 & 16.36 & 9 & 16.36 \\
\hline \multirow[t]{2}{*}{ Total } & 7 & 12.73 & 48 & 87.27 & 55 & 100 \\
\hline & \multicolumn{4}{|c|}{ Prilaku Gizi Seimbang } & \multirow{2}{*}{\multicolumn{2}{|c|}{ Total }} \\
\hline \multirow[t]{2}{*}{ Kejadian Sakit } & \multicolumn{2}{|c|}{ Sedang } & \multicolumn{2}{|c|}{ Baik } & & \\
\hline & $\mathbf{n}$ & $\%$ & $\mathbf{n}$ & $\%$ & $\mathbf{N}$ & $\%$ \\
\hline Pernah sakit & 7 & 12.73 & 46 & 83.64 & 53 & 96.36 \\
\hline Tidak pernah sakit & 0 & 0 & 2 & 3.64 & 2 & 3.64 \\
\hline Total & 7 & 12.73 & 48 & 87.27 & 55 & 100 \\
\hline
\end{tabular}

Hasil uji korelasi Spearman juga menunjukkan bahwa tidak terdapat hubungan yang signifikan antara perilaku gizi seimbang ibu dengan kejadian sakit contoh. Hal tersebut berarti bahwa ibu yang berperilaku gizi seimbang dengan baik belum tentu balitanya tidak pernah sakit.

\section{KESIMPULAN}

Sebagian besar pengetahuan gizi ibu tergolong sedang, yakni sebanyak 61.82 per- 
sen, serta tidak terdapat ibu yang memiliki pengetahuan gizi rendah. Lebih dari 50 persen ibu memiliki PHBS dalam lingkungan keluarga yang tergolong sedang dan termasuk ke dalam kategori keluarga sehat 3. Sementara itu, 87.27 persen perilaku gizi seimbang ibu tergolong ke dalam kategori baik.

Rata-rata tingkat kecukupan energi contoh masih tergolong defisit tingkat ringan sebab hanya mencapai 84.6 persen (< AKE aktual), sedangkan rata-rata tingkat kecukupan protein contoh tergolong berlebih. Rata-rata kecukupan vitamin dan mineral contoh tergolong cukup, yakni >77 persen angka kecukupan vitamin dan mineral. Sebagian besar status gizi contoh tergolong normal, namun meski demikian, pada indeks BB/U masih terdapat sebanyak 1.82 persen contoh yang termasuk gizi buruk. Hampir semua contoh pernah mengalami sakit selama satu bulan terakhir, dengan rata-rata frekuensi sakit 1-2 kali dalam satu bulan, serta dengan lama sakit rata-rata 1-3 hari.

Pengetahuan gizi berkorelasi positif dengan PHBS dalam keluarga $(p \varangle 0.05$ dan $r=0.706)$, serta berkorelasi dengan perilaku gizi seimbang ibu $(p \ll 0.05$ dan $r=0.537)$. Hal tersebut menunjukkan bahwa semakin baik pengetahuan gizi ibu maka semakin baik pula penerapan PHBS dalam keluarga serta perilaku gizi seimbangnya. Perilaku gizi seimbang ibu tidak berhubungan dengan kecukupan energi dan zat gizi contoh. Hal ini diduga karena adanya faktor-faktor lain yang ikut mempengaruhi kecukupan energi dan zat gizi, selain perilaku gizi seimbang ibu. Kecukupan energi dan zat gizi juga tidak berkorelasi terhadap status gizi contoh $(p>0.05)$. Beberapa faktor lain yang diduga ikut mempengaruhi status gizi antara lain kondisi sakit atau infeksi tertentu, serta kualitas dan kuantitas makanan yang dikonsumsi.

PHBS dalam lingkungan keluarga berkorelasi positif dengan status gizi contoh $(p<0.05$ dan $r=0.325)$, namun PHBS keluarga tidak berkorelasi dengan kejadian sakit pada contoh $(p>0.05)$. Perilaku gizi seimbang ibu tidak berkorelasi dengan status gizi contoh $(p>0.05)$ serta kejadian sakit pada contoh $(p>0.05)$. Hal tersebut menunjukkan bahwa tidak selalu ibu yang berperilaku gizi seimbang akan memiliki balita dengan status gizi yang selalu baik serta tidak pernah sakit.

Saran yang dapat diberikan adalah mengenai pengetahuan gizi ibu yang masih tergolong kurang, khususnya tentang fungsi zat-zat gizi bagi tubuh serta jenis-jenis pangan sumber zat gizi. Oleh karena itu, sebaiknya perlu adanya sosialisasi di posyandu atau puskesmas dengan intensitas yang cukup sering kepada para ibu agar dapat benar-benar memahami dan mengingat materi yang berkaitan dengan pengetahuan gizi tersebut, sehingga dapat meningkatkan konsumsi pangan, status gizi, serta kesehatan balita.

Tidak semua ibu yang memiliki tingkat pendidikan dan pengetahuan gizi yang tinggi, melakukan perilaku gizi seimbang dengan baik. Rata-rata ibu yang bekerja di luar rumah, cenderung memiliki waktu yang kurang untuk mengontrol pola makan dan pola hidup bersih anak balitanya. Hal ini seharusnya lebih diperhatikan oleh para kader, tenaga kesehatan, serta para ibu, khususnya yang memiliki balita. Sosialisasi mengenai perilaku gizi seimbang dalam keluarga perlu dilakukan untuk meningkatkan kesadaran serta kepedulian ibu terhadap gizi dan kesehatan anggota keluarga.

\section{DAFTAR PUSTAKA}

[Bappeda] Badan Pembangunan Daerah. 2008. Rencana Strategis Kabupaten Bojonegoro 2007-2012. Badan Pembangunan Daerah, Boj onegoro.

[BPS] Badan Pusat Statistik Provinsi Jawa Timur. 2010. Berita Resmi Statistik: Profil Kemiskinan di J awa Timur tahun 2010.

[Depkes RI] Departemen Kesehatan RI. 2006. Promosi Kesehatan: Buku Saku Bidan Poskesdes. Departemen Kesehatan RI, J akarta.

[Dinkes] Dinas Kesehatan Kabupaten Bojonegoro. 2008. Profil Kesehatan Kabupaten Bojonegoro Tahun 2008.

Effendi YH, Ekayanti I, \& Nurdin NM. 2010. Bioetika dan Kesehatan Masyarakat. Fakultas Ekologi Manusia, Institut Pertanian Bogor, Bogor.

Hardinsyah \& Martianto D. 1988. Menaksir Kecukupan Energi dan Protein serta Mutu Gizi Konsumsi Pangan. Wirasari, Jakarta.

Khomsan A. 2000. Teknik Pengukuran Pengetahuan Gizi. Fakultas Ekologi Manusia, Institut Pertanian Bogor, Bogor. 
Khomsan A, Anwar F, Sukandar D, Riyadi $H, \&$ Mudjajanto ES. 2009. Studi Peningkatan Pengetahuan Gizi Ibu dan Kader Posyandu serta Perbaikan Gizi Balita. Fakultas Ekologi Manusia, Institut Pertanian Bogor, Bogor.

Kurniasih D, Hilmansyah $\mathrm{H}$, Astuti MP, \& Imam S. 2010. Sehat dan Bugar Berkat Gizi Seimbang. Gramedia, Jakarta.

Lemeshow S, David WH, \& Janelle K. 1997. Besar Sampel dalam Penelitian Kesehatan (Pramoni D, penerjemah). UGM Press, Yogyakarta.

Riyadi H. 2003. Metode Penilaian Status Gizi secara Antropometri. Fakultas Ekologi
Manusia, Institut Pertanian Bogor, Bogor.

Slamet Y. 1993. Analisis Kuantitatif untuk Data Sosial. Dabara Publisher, Solo.

Soekirman. 2000. IImu Gizi dan Aplikasinya: untuk Keluarga dan Masyarakat. Direktorat J enderal Pendidikan Tinggi, Departemen Pendidikan Nasional.

Stalker P. 2008. Millennium development goals MDGs). www.undp.or.id/ pubs/ docs/ Let SpeakOutforMDGs. pdf [2 Feb 2011].

[WHO] World Health Organization. 2006. WHO Anthro 2005 for personals computers manual. http:/ who.int/ childgrowth/ soft ware [11 Feb 2011]. 